\title{
Wear debris: basic features and machine health diagnostics
}

\author{
M. A. Khan, A. G. Starr \\ Through Life Support Research Group, School of Mechanical, Aerospace and Civil Engineering, \\ The University of Manchester, M60 1QD, UK. \\ Tel :(44) (0) 161306 5724, Fax :(44) (0) 1613064601 \\ muhammad.khan-8@postgrad.manchester.ac.uk \\ a.starr@manchester.ac.uk
}

\begin{abstract}
Modern high speed and power machinery components like gears, bearings, pumps, hydraulics and motors normally suffer from wear phenomena during operation. The study of wear debris can help estimate the condition of the surface of a component, so its basic features may be used to diagnose component health prior to failure. In this paper, a review is presented of the current literature related to wear debris and its analysis. The basic features of wear debris are highlighted, and their possible potential to diagnose the health of machine components is discussed. The basic features of wear debris have been classified with respect to the approach of measurement for component health diagnostics. In addition, each feature has been detailed with its possible measurement descriptors, its trend during machine component operation, and its distinct health diagnostics capability. Finally the paper proposes advances in machine component health diagnostics solution, by optimising the diagnostic capabilities of basic wear debris features.
\end{abstract}

Keywords: Wear, wear debris basic features, wear debris detection descriptors, machine component health diagnostics.

\section{INTRODUCTION}

The term wear debris may be defined as the particles which are generated in a mechanical system (like turbines, generators and engines), when the system components (like gears and bearings) are degraded due to wear phenomena in such a way that the degradation causes material loss. In common observation the wear debris is basically solid, but properties like softness or elasticity may tend the shape to be similar to slurry rather than a solid ${ }^{(1)}$. Usually debris is formed from the surface interactions of components of any system, so basic features of the debris may contain valuable information regarding the wear mechanisms, the modes occurring at the location of interaction and the effects of wear on component health ${ }^{(2)}$.

It is observed that wear debris particles are widely varying in size, distribution and other feature properties, but that their source and behaviour is important in condition monitoring and maintenance decision-making. In the sections below we consider classification, size, quantity and concentration and their trends, the size distribution, shape, and composition. The treatment is generalised across a wide range of machinery, so precise dimensions have been deliberately omitted in places - a particle which is "large" for a hydraulic system is trivial in a marine gearbox - but trends in behaviour are emphasised.

\section{CLASSIFICATION OF WEAR DEBRI S BASIC FEATURES}

With respect to the approach of debris measurement for the determination of component health diagnostics, wear debris basic features, can be classified into three categories ${ }^{(1-15)}$ :

- Quantitative;

- Qualitative;

- Material properties.

The wear debris features within these three categories are shown in table 1. 


\begin{tabular}{|l|c|l|l|}
\hline Classification Category & Quantitative & Qualitative & Material \\
\hline Basic Features & $\bullet$ Size & $\bullet$ Shape & $\bullet$ Composition \\
& $\bullet$ Quantity/Concentration & & \\
\hline
\end{tabular}

Table 1. Classification of wear debris basic features

\section{QUANTITATIVE FEATURE 'SIZE'}

The bodily magnitude of any wear debris is usually termed its size. But factors like porosities, surface roughness and complexity in the physical contours make it hard to define an accurate measurement scheme for size.

According to the literature ${ }^{(4,16)}$, two types of measurement descriptors can be used to measure the size of wear debris, as detailed below.

\subsection{Optical size measurement (OSM) descriptors}

OSM descriptors are used to determine the size of wear debris by means of visual dimensional analysis. The following are some useful OSM descriptors.

- Largest diameter - the longest dimension of wear debris.

- Feret's diameter - the maximum distance between two parallel lines, set at a fixed angle and just touching the physical contour of the wear debris. (The debris should be positioned in a defined orientation).

- Martin's diameter - the breadth of wear debris, where a fixed angle line bisects the debris overall projected area into two equal areas.

- Volume diameter - the diameter of a sphere whose volume is the same as that of the wear debris.

- Free falling diameter - the diameter of a sphere having the same free-falling speed as the wear debris.

- Stokes's diameter - the free falling diameter in the laminar flow region.

- Axial ratio - the ratio of breadth and longest dimension of the wear debris.

\subsection{Non-optical size measurement (NSM) descriptors}

NSM descriptors are used to determine the size of wear debris by correlating its physical actions to its size value, for example the ability of the debris to block the machine lubricant lines or choke the filters. Similarly the strength of the wear debris can act as an attribute to increase the component wear phenomena.

\subsection{General trends of wear debris 'size' features in machine component operation}

The trends of wear debris size are different for different types of wear occurring during machine component operation. For steel and steel based alloys, the following five basic wear types dominate, according to Anderson ${ }^{(17)}$ and Bowen et al ${ }^{(18)}$.

- Rubbing/break in wear - found as normal benign wear in sliding surfaces.

- Cutting - usually occurs as abnormal abrasive wear due to the interpenetration of sliding wear.

- Rolling fatigue - usually occurs in rolling element bearings and gear systems as a result of fatigue wear mode.

- Combined rolling and sliding - occurs in the abnormal wear regime of wear fatigue mode and scuffing wear. 
- Severe sliding - occurs due to excessive load and high speed.

The trends of wear debris size for the above are given in table 2 .

\subsection{Diagnostic capability of the wear debris 'size' feature}

Information from the quantitative size features is distinctly useful for diagnosing wear process severity during machine component operation, according to Roylance and Raadnui ${ }^{(10)}$. As the size of wear debris increases, so the area of surface degradation on the machine component increases too. And as the surface degradation area on machine component increases, so does the severity of the wear process taking place. Mathematically we can say,

$$
\text { Wear debris size } \alpha \text { Wear process severity }
$$

\section{QUANTITY AND CONCENTRATION}

The total physical amount of wear debris present in the lubricant of any machine is commonly termed its quantity or concentration. Regardless of its appropriateness, the term 'mass' for this feature is not often used in the available literature on wear debris.

\subsection{Quantity measurement descriptors}

The following five basic quantity measurement descriptors can be used for wear debris, according to Leschonski ${ }^{(19)}$.

- Number - utilizing a counting process for wear debris quantity

- Length - measuring the length of the surface where all the wear debris are placed.

- Area - measuring the physical area of the surface where all wear debris are placed.

- Volume - utilizing volume measuring apparatus for quantifying wear debris.

- Weight/mass - for example the increased weight of a filter paper due to the wear debris after a lubricant sample is filtered.

\subsection{General trends of quantity features in machine component operation}

Tracking the wear progress through monitoring of the wear debris concentration or quantity as a function of time is one of the primary objectives of condition monitoring for a machine component. Moubray $^{(20)}$ has described six patterns to represent the range of possible trends of the quantity during any machine component operation. By using these patterns, hypothetical quantity feature trends during machine component operation are explained below in the context of wear.

\subsubsection{Trend-1}

In this trend, as shown in figure 1, wear debris are initially generated in large quantity with a decreasing trend ("running in" wear). This is similar to the common "bath tub" curve, usually applied to the whole life population-specific failure rate or hazard plot. With time the decreasing trend stabilizes and then follows a zone of operation in which wear debris are generated at a constant rate. This is termed the middle zone or "useful life" period. As the time passes, the middle zone comes to an end and once again wear debris are generated in large quantity but this time with increasing trend, which continues until component failure.

\subsubsection{Trend-2}

In trend 2, as shown in figure 2, as operation starts, wear debris are generated at a constant rate. This constant mode remains for most of component life, and is followed by a failure zone at the end, in which a large quantity of wear debris is generated with increasing trend.

\subsubsection{Trend-3}

In trend 3 , as shown in figure 3 , the wear debris quantity increases linearly with time. 


\subsubsection{Trend-4}

In trend 4 , as shown in figure 4 , at the start the wear debris is generated in large quantity with increasing trend, but after some time the trend of quantity generation becomes constant and remains so until component failure.

\subsubsection{Trend-5}

In trend 5, as shown in figure 5, wear debris generation is constant throughout the whole component life.

\subsubsection{Trend-6}

In trend 6 , as shown in figure 6 , at the start the wear debris is generated in large quantity with decreasing trend, but after some time the trend of quantity generation becomes constant and remains so until component failure.

\subsection{Diagnostic capability of the wear debris quantity feature}

The information contained in the quantitative features of wear debris analysis distinctly diagnoses wear rate during machine component operation, according to Neale et al ${ }^{(21)}$. From the trend discussion above, it may be understood that during the whole life cycle of a machine component, generated wear debris appear at different rates. By the study of the quantity features, one can determine the rate of wear by using following relationship.

$$
\text { Wear rate }=\frac{\text { Current wear debris level }- \text { Immediately previous wear debris level }}{\text { Time between the measurements }}
$$

\section{QUANTIFICATION OF SIZE DISTRIBUTION}

The wear debris size distribution changes during the component life, and is one of the key characteristics which can be used as the basis for machine health diagnosis. It is basically a representation of overall wear debris generated during any machine wearable component operation with respect to size. But the effectiveness of diagnosis on the basis of this characteristic will become less as contamination in the system increases ${ }^{(22)}$.

\subsection{Size distribution measurement descriptors}

There are number of ways to measure the size distribution of generated wear debris during machine component operation, but two broad classifications can be made ${ }^{(17,19,22-24)}$.

- Statistics based descriptors - based on metrics like mean, standard deviation, skewness and kurtosis.

- Probability based descriptors - based on probability functions like uniform distribution, exponential distribution, normal distribution, gamma distribution and Weibull distribution.

\subsection{General trends of wear debris size distribution in machine component operation}

In machine systems there are generally three major operating zones from initiation to failure: running in, useful operation and rapid wear. The zones are influenced by different wear modes and different trends of wear debris size distribution. Figure 7 demonstrates the variability in size distribution trends from initial life to failure of the machine system.

As illustrated in figure 7, during the initial stages or running in zone, the machine component begins to be affected by the wear process and small particles are generated at a high rate, usually attributed to the removal of asperities left by manufacturing processes. As the system passes this running-in zone, no important change in size distribution is observed. Only the quantity rate is decreasing, and the size of generated debris is consistent which does not alter the size distribution curve. But as the machine component leaves this running-in zone, an increase in size and a gradual decrease in rate of quantity of generated debris occurs. With size increasing and quantity rate decreasing, the machine component 
enters into the useful operating life zone. This zone possesses an overall uniform size distribution trend of particles larger in size, but smaller in quantity, than running-in wear. And at the end of this useful operating life zone, the machine component enters the rapid wear zone, in which both rate of quantity and size of generated debris increase rapidly and the rising trend continues until ultimate failure.

It should be noted that small debris may be counted in very large numbers, in the order $10^{6}$ to $10^{8}$ particles per $100 \mathrm{ml}$ for some machines, while the large debris in the wear zone may be counted in much smaller numbers, in the order $10^{4}$ to $10^{6}$ particles per $100 \mathrm{ml}^{(25)}$.

\subsection{Diagnostic capability of the wear debris size distribution}

The information obtained from the quantification of the size distribution of the wear debris diagnoses zones of wear and their transition times during machine component operation. Through the determination of zones of wear and the wear transition time, a useful conclusion for machine component health diagnostics and prognostics can be made. The transition from the useful operational life zone to the rapid wear zone is of particular interest, because it gives a clear warning of the onset of an irreversible degradation and finite life.

\section{QUALITATIVE FEATURE 'SHAPE'}

Generally, the term shape for wear debris denotes two distinct characteristics of the debris, which are form and proportions ${ }^{(26)}$. Form describes the tendency of a particle to become a definite geometrical (either regular or irregular) structure like a cube or a sphere. While proportion describes the relative ratio of difference between the same class of geometrical structures like cuboids and spheroids. To define the shape of wear debris in a more comprehensive way, this relative ratio of difference may be further analyzed in qualitative terms, e.g. debris edge details and its surface texture.

\subsection{Shape measurement descriptors}

Physical form, edge details and surface texture, which are the three basic characteristics of shape feature, have a large variety of descriptors for their measurements. Some of the important ones are listed below $(4,10,16)$

\subsubsection{Physical form measurement descriptors}

These descriptors are based on debris macroscopic dimensional analysis.

- Aspect ratio - length to width ratio of debris.

- Elongation - length to width ratio along the debris shape.

- Roundness.

- Circularity.

- Sphere diameter - ratio of two times debris area and its perimeter.

6.1.2. Surface texture and edge detail measurement descriptors

These descriptors are based on microscopic dimensional analysis of the particles.

- Fourier descriptor - consists of finding the centre of gravity of debris and its perimeter.

- Fractal dimension - an irregular debris shape enclosed by polygons of constant sides. These sides and perimeter of polygons determine the characteristic surface texture factor.

- Curvature determiner - using changes of angle that occur along the perimeter by successively moving three adjacent points on debris, and measuring the inclusive angle formed by the projecting two lines through the points such that they intersect at the middle point. 


\subsection{General trends of shape features in machine component operation}

General trends of the wear debris shape features can comprehensively understood by describing the trends with respect to its physical appearance, as described in table $3^{(1,4,5,21,27)}$. There are several types of shapes observed, and attention must be paid to their specific sizes, because these are linked to particular degradation mechanisms. Shapes include spheres, ovoids, chunks and slabs, platelets and flakes, curls, spirals and slivers, rolls and long thin particles. Generally the trend is increasing quantity and size with severity.

\subsection{Diagnostic capability of wear debris shape features}

Information arising from the qualitative shape features from wear debris may be used to diagnose both the wear type and mode ${ }^{(1,3,5,7,10,28)}$. All the five wear types as discussed above in section 3.3 have distinguishable shape features, as illustrated by figure 8 shown below. As a result, the shape can help identify the likely wear types occurring in the machine component. The wear type can then be used to predict the wear mode by utilizing the mapping as provided in figure 9.

\section{MATERIAL FEATURE: COMPOSITION}

By using the diagnostic capabilities of both quantitative and qualitative features, it is possible to establish appropriate alarms and limits to predict and identify impending machine component failure. But in order to further localize the source of the wear metal production, and hence guide the necessary maintenance actions, information on composition is important ${ }^{29)}$. The chemical composition of the wear debris is able to provide a much better idea of the source, as compared to the other characteristics like shape and size distribution.

\subsection{Composition measurement descriptors}

The descriptors of composition vary widely according to the type of measurement techniques. The most common descriptors are described below in two separate categories ${ }^{(1,4,5,21)}$.

\subsubsection{Micro property descriptors}

- Elemental content - the percentage of different elements in a wear debris oil sample is measured by atomic absorption or emission spectrometry.

- Molecular content - the percentage of different molecular structures in a wear debris oil sample can be measured by infra red spectrometry.

7.1.2. Macro property descriptors

- Colour

- Impact hardness

- Relative density

- Conductivity

- Polarity

- Specific heat capacity

\subsection{Elements and their sources in general machine components}

Hunt presented a detailed chart of elements and their related components in general mechanical systems $^{(1,4)}$. It covers the main 20 elements and their respective sources as given in table 4 . It may be observed that the main machine elements are broadly distinguishable because of different basic composition, alloying or additives. It is also important to note that some components of similar composition would be indistinguishable from each other unless labelled, e.g. with a different alloy. 


\subsection{Diagnostic capability of the composition of wear debris}

The most prominent diagnostic capability of the composition of wear debris is to localize the source as discussed above. This can be considered to be an advanced diagnosis, because it becomes important after the initial detection of change, and the advancing trend of other patterns discussed above, such as quantity. Some techniques can combine the monitoring of both composition and quantity, as long as limitations of the technology are considered - for example, spectrometric techniques will vaporise small particles suspended in the oil, but may have problems handling large particles.

\section{CONCLUSIONS AND FURTHER WORK}

This paper has reviewed wear debris classification, the analysis of size, quantity and concentration and their trends, size distribution, shape, and composition. An ideal diagnostic model for a machine system and its components should give an early diagnosis of degrading health, with accurate prognostics to enable maintenance decisions to be made, well before damage and catastrophic failure. However, it is difficult to establish such a model for a real machine, for the following reasons.

- The machine component working behaviour or trend cannot be predicted exactly. The estimation of future behaviour is always subject to uncertainty.

- Debris feature extraction and calculation techniques require compromises and assumptions due to the complex and intricate detail properties of the debris.

- The development and application of an ideal diagnostic model on a maintainable machine system may be excessively costly.

- Currently detection techniques are not capable of diagnosing all features in real time.

There are several ways to optimise a model by further research. Considering the capabilities of wear debris machine component health diagnostics discussed above, a hypothetical component health diagnostic model is proposed below.

\subsection{Hypothesis for a component health diagnostic model}

For a hypothetical component health diagnostic model, five features of measurement descriptors for size, quantity, size distribution, shape and composition are proposed in table 5, with their reasons for selection. The proposed diagnostic model is based on these five descriptors and one diagnostics information evaluator as illustrated by figure 11 and figure 12 .

In figure 11, the descriptors are shown by the inputs $\mathrm{Ai}, \mathrm{Bi}, \mathrm{Ci}, \mathrm{Di}$ and $\mathrm{Ei}$ applied to the wear debris. On application, they will generate useful diagnostics within their capabilities. A diagnostic evaluator is also included, which takes the diagnostic information (i.e. the outputs Ao, Bo, Co, Do and Eo as shown in figure 11) and applies the evaluation rules as shown in figure 12. The component health diagnosis is performed by an intelligent rule application process. The illustrations of the model (figure 11 and 12) are intended to generate machine health information like wear severity, rate, mode, type, source, zone and transition time, by using well defined evaluation rules.

\subsection{Future work}

The model hypothesis above is a proposal and verification will be performed by the doing the following future work:

- experimental work using offline sampling on a gear tester machine to check the authenticity of the diagnostic capabilities of basic wear debris features as discussed above;

- basic wear debris feature descriptors will be modified after validation (if required) and then implemented;

- automation of the proposed model from debris collection to machine health estimation will be developed and validated. 


\section{Table Captions:}

Table 2

Table 3

Table 4

Table 5
Size trends vs Wear particle type ${ }^{(17)}$

General trends of debris shape in machine system ${ }^{(1,4,5,21,27)}$

Elements mapping with possible sources ${ }^{(4)}$

Measurement descriptors for hypothetical component health

diagnostic model 
Figure Captions:

Figure 1

Figure 2

Figure 3

Figure 4

Figure 5

Figure 6

Figure 7

Figure 8

Figure 9

Figure 10

Figure 11

Figure 12
Quantity feature Trend 1

Quantity feature Trend 2

Quantity feature Trend 3

Quantity feature Trend 4

Quantity feature Trend 5

Quantity feature Trend 6

Size distribution trend for a general machine component operation ${ }^{(21)}$

General wear debris shapes

Different shapes of different wear type debris ${ }^{(28)}$

Mapping between wear types and wear modes ${ }^{(1)}$

Proposed wear debris features diagnostic model

Diagnostic Evaluator 
Table-2:

\begin{tabular}{|l|l|l|}
\hline S.No & Wear type & Wear debris size trends \\
\hline 1 & Rubbing wear/Break in wear & $\begin{array}{l}0.5 \mu \mathrm{m}-15 \mu \mathrm{m} \text { or less in major dimension } / 5 \mu \mathrm{m}-15 \mu \mathrm{m} \text { and for } \\
\text { worst condition it may increase to } 50 \mu \mathrm{m}-200 \mu \mathrm{m} \text { and can increase } \\
\text { more if an interaction occurs between break in wear and excessive } \\
\text { contamination. } \\
\text { Major dimension to thickness ratio is } 10: 1 \text { for large particle and } 3: 1 \\
\text { for small particle i.e. } 0.5 \mu \mathrm{m} .\end{array}$ \\
\hline 2 & $\begin{array}{l}2 \mu \mathrm{m}-5 \mu \mathrm{m} \text { wide \& } 25 \mu \mathrm{m}-100 \mu \mathrm{m} \text { long and due to effect of } \\
\text { contaminants the available range is } 0.25 \mu \mathrm{m} \text { with } 5 \mu \mathrm{m} .\end{array}$ \\
\hline 3 & $\begin{array}{c}\text { Rolling fatigue } \\
10 \mu \mathrm{m}-100 \mu \mathrm{m} \text { with a major dimension to thickness ratio of } 10: 1\end{array}$ \\
& $\quad$ Spall particles & $3 \mu \mathrm{m}-10 \mu \mathrm{m}$ \\
\hline 4 & $\begin{array}{c}\text { Combined rolling and sliding } \\
20 \mu \mathrm{m}-50 \mu \mathrm{m} \text { with a major dimension to thickness ratio of } 30: 1\end{array}$ \\
\hline 5 & Severe sliding wear & $\begin{array}{l}2 \mu \mathrm{m}-20 \mu \mathrm{m} \text { with a major dimension to thickness ratio between } 4: 1 \\
\text { to } 10: 1\end{array}$ \\
\hline
\end{tabular}


Table-3:

\begin{tabular}{|c|c|c|c|c|}
\hline S.No. & Physical Appearance & Possible Sketch & Possible origins & Possible Trends in machine wear \\
\hline 1 & $\begin{array}{l}\text { Spheres } \\
\text { (Metallic spheres } \\
\text { between of } 0.5 \mu \mathrm{m} \text { to } \\
20 \mu \mathrm{m} \text { in diameter) }\end{array}$ & See figure 8 & $\begin{array}{l}\text { 1. Metal fatigue } \\
\text { (especially in } \\
\text { bearings) } \\
2 . \\
\text { 'sparks' Welding } \\
\begin{array}{l}\text { 3. Glass peen } \\
\text { beads }\end{array}\end{array}$ & $\begin{array}{l}\text { Usually spherical particles start } \\
\text { to appear around } 60 \% \text { through } \\
\text { the life of bearing. By } 80 \% \text { - } \\
90 \% \text { through the life they usually } \\
\text { can be observed in large } \\
\text { quantities, increasing rapidly } \\
\text { towards failure. }\end{array}$ \\
\hline 2 & $\begin{array}{l}\text { Distorted } \begin{array}{l}\text { Smooth } \\
\text { ovoids (pebbles or } \\
\text { granular) }\end{array} \\
\text { 1. Black granular } \\
\text { particles of iron oxide } \\
\text { vary in size up to } 150 \\
\mu \mathrm{m} \text { but more are less } \\
\text { than } 5 \mu \mathrm{m} \text { in length. } \\
2 . \text { Orange or red } \\
\text { granular particles of } \\
\text { iron oxide vary in size } \\
\text { up to } 150 \mu \mathrm{m} . \\
3 . \\
\text { particles, Atmospheric } \\
\text { and grit, swarf, rust, } \\
\text { paint etc. }\end{array}$ & See figure 8 & $\begin{array}{l}\text { 1. Oxidative wear } \\
\text { of iron } \\
\text { 2. Quarry dust } \\
\text { 3. Atmospheric } \\
\text { dust from material } \\
\text { like seals, breather } \\
\text { etc. }\end{array}$ & $\begin{array}{l}\text { Black and orange granular } \\
\text { particles are mostly due to } \\
\text { oxidative wear and commonly } \\
\text { caused by excessive component } \\
\text { operating temperatures and/or } \\
\text { inadequate lubrication. } \\
\text { Atmospheric particles enter } \\
\text { inside the machine system due to } \\
\text { poor sealing and may intensify } \\
\text { the wear process or make } \\
\text { blockage in lubricant paths. }\end{array}$ \\
\hline 3 & $\begin{array}{l}\text { Chunks and slabs } \\
\text { (Coarse, dull grey } \\
\text { appearance with highly } \\
\text { polished bright spots, } \\
\text { irregular metal particles } \\
\text { with length and width } \\
\text { and thickness of same } \\
\text { order of about } 1 \mathrm{~mm} \\
\text { during severe pitting) }\end{array}$ & See figure 8 & $\begin{array}{l}\text { 1. Metal fatigue } \\
\text { (surface fatigue of } \\
\text { gears) } \\
\text { 2. Bearing pitting } \\
\text { 3. Rock debris }\end{array}$ & $\begin{array}{l}\text { Fatigue spalls, pitting and break } \\
\text { up produce chunks of sharp } \\
\text { rough metals. While rough slabs } \\
\text { are generated by sliding action or } \\
\text { by fatigue involving very high } \\
\text { temperature or inadequate } \\
\text { lubrication. }\end{array}$ \\
\hline 4 & $\begin{array}{l}\text { Platelet and flakes } \\
\text { 1. Very large metal } \\
\text { flakes often above } 1 \\
\mathrm{~mm} \text { in length, some } \\
\text { times appearing as } \\
\text { rounded petals. } \\
2 . \text { Large metal flakes } \\
\text { about } 1 \mathrm{~mm} \text { in length. } \\
\text { Usually curled } \\
\text { rectangular in shape. } \\
3 . \text { Medium size flakes } \\
\text { of } 150 \mu \mathrm{m} \text { to } 1 \text { mm size } \\
\text { in length, severely torn } \\
\text { and plastically worked. } \\
\text { Solder-like balls can } \\
\text { also be formed for low } \\
\text { melting point materials. } \\
4 . \text { Medium sized flakes } \\
\text { of } 15 \mu \mathrm{m} \text { to } 1 \text { mm size } \\
\text { in length, roughly torn } \\
\text { with evidence of plastic } \\
\text { flow. } \\
5 . \text { Small sized flakes of } \\
1 \mu \mathrm{m} \text { to } 15 \mu \mathrm{m} \text { in length }\end{array}$ & See figure 8 & $\begin{array}{l}\text { 1. Fatigue failures } \\
\text { of plain, rolling } \\
\text { and ball bearing } \\
\text { 2. Piston rings } \\
\text { scuffing } \\
\text { 3. Plain bearing } \\
\text { wiping } \\
\text { 4. Piston cylinders } \\
\text { 5. Surface fatigue } \\
\text { of gears }\end{array}$ & $\begin{array}{l}\text { 1. Very large flakes usually } \\
\text { appear in rapid failure zone and } \\
\text { their presence shows that total } \\
\text { failure is likely to be imminent. } \\
\text { 2. Large flakes are usually very } \\
\text { thin with feathery edges caused } \\
\text { by surface fatigue in rapid failure } \\
\text { zone. } \\
\text { 3. Medium size flakes usually } \\
\text { appear when catastrophic sliding } \\
\text { wear occurs, which tends towards } \\
\text { a complete breakdown of } \\
\text { component surfaces. } \\
\text { 4. Medium size flakes are often } \\
\text { found when soft materials (like a } \\
\text { piston) are under wear; due to } \\
\text { localized adhesion they tend to } \\
\text { exhibit larger particles and higher } \\
\text { wear rates. } \\
\text { 5. Small metal flakes are often } \\
\text { found during running-in wear. }\end{array}$ \\
\hline
\end{tabular}




\begin{tabular}{|c|c|c|c|c|}
\hline & $\begin{array}{l}\text { with } 1 \mu \mathrm{m} \text { or less in } \\
\text { thickness. }\end{array}$ & & & $\begin{array}{l}\text { Many of these flakes are formed } \\
\text { during the starting and stopped of } \\
\text { a machine. }\end{array}$ \\
\hline 5 & $\begin{array}{l}\text { Curls, spirals } \\
\text { and slivers }\end{array}$ & See figure 8 & $\begin{array}{l}\text { Machining debris } \\
\text { produced at high } \\
\text { temperature }\end{array}$ & $\begin{array}{l}\text { The spiral debris is produced by } \\
\text { a ploughing action in valves and } \\
\text { bearings where a harder part of a } \\
\text { component, or a sharp ingested } \\
\text { particle, digs into softer surface. } \\
\text { Usually occurs in loose fitting } \\
\text { components like poor housing to } \\
\text { a bearing race. }\end{array}$ \\
\hline 6 & Rolls & See figure 8 & $\begin{array}{l}\text { Probably similar to } \\
\text { platelets but in } \\
\text { rolled form }\end{array}$ & $\begin{array}{l}\text { A roll is a sort of combination of } \\
\text { spiral and platelets. Their } \\
\text { generation and behaviour in a } \\
\text { wear process is same as platelets. }\end{array}$ \\
\hline 7 & $\begin{array}{l}\text { Long thin particles } \\
\text { 1. Large metal splinters } \\
\text { of several } \mathrm{mm} \text { in length } \\
\text { 2. Smaller splinters of } \\
\text { metal of about } 1 \mathrm{~mm} \text { in } \\
\text { length } \\
\text { 3. Tiny short hair-like } \\
\text { strands of metal about } \\
100 \mu \mathrm{m} \text { in length } \\
4 . \quad \text { Miniature metal, } \\
\text { spirals, loops and bent } \\
\text { wires of about } 100 \mu \mathrm{m} \\
\text { in length. } \\
5 . \quad \text { Rolling pins of } \\
\text { polymeric materials } \\
\text { with a size } 5 \mu \mathrm{m} \text { to } 25 \\
\mu \mathrm{m} \text { in length. }\end{array}$ & See figure 8 & $\begin{array}{l}\text { 1. Labyrinth seals } \\
\text { 2. Gear teeth, } \\
\text { Circlip washer etc. } \\
\text { 3. Needle roller } \\
\text { bearing } \\
\text { 4.Polymers }\end{array}$ & $\begin{array}{l}\text { Usually an increase of long thin } \\
\text { particles shows an indication of } \\
\text { metal deterioration increase. } \\
\text { Thin particles like polymeric } \\
\text { materials can cause increase in } \\
\text { severity of wear specially in } \\
\text { manufacturing machine systems } \\
\text { by acting as contaminants. }\end{array}$ \\
\hline
\end{tabular}


Table-4:

\begin{tabular}{|l|l|l|}
\hline S.No. & Element & Possible Sources \\
\hline 1 & Aluminium & $\begin{array}{l}\text { Spacers, shims, washers, pistons on reciprocating engines, cases on } \\
\text { accessories, bearing cages in planetary gears, crankcase in reciprocating } \\
\text { engines and bearing surfaces. }\end{array}$ \\
\hline 2 & Antimony & Bearing alloys, grease. \\
\hline 3 & Barium & Oil additive, grease, water (leaks). \\
\hline 4 & Boron & Seals, airborne dust, water, coolants. \\
\hline 5 & Calcium & Oil additive, grease, some bearings. \\
\hline 6 & Chromium & $\begin{array}{l}\text { Plating metal, seals, bearings cages, piston rings, cylinder walls in } \\
\text { reciprocating engines, chromate corrosion inhibitors. }\end{array}$ \\
\hline 7 & Copper & $\begin{array}{l}\text { Main or rod bearing thrust bearings, wrist pin bushes, oil coolers, gears, } \\
\text { valves, turbocharger bushes, washers, copper radiator. }\end{array}$ \\
\hline 8 & Iron & $\begin{array}{l}\text { Cylinder walls, valves guides, rocker arms, piston rings, ball and roller } \\
\text { bearings, bearing races, spring gears, safety wire, lock washers, locking nuts, } \\
\text { locking pins, bolts. }\end{array}$ \\
\hline 9 & Lead & Bearing metal, seals, solder, paints, grease. \\
\hline 10 & Manganese & Valves, blowers, exhaust and intake systems. \\
\hline 11 & Magnesium & Aircraft engine case for accessories, component housing, marine equipment. \\
\hline 12 & Molybdenum & Piston rings, electric motors. \\
\hline 13 & Nickel & Bearing metal, valve train metals, turbine blades. \\
\hline 14 & Phosphorus & Coolant leak, Oil additive. \\
\hline 15 & Silicon & Airborne dust, seals. \\
\hline 16 & Silver & $\begin{array}{l}\text { Bearing cages, puddle pumps, gear teeth, shafts, bearing in reciprocating } \\
\text { engines. }\end{array}$ \\
\hline 17 & Sodium & Coolant leaks, grease, marine equipment. \\
\hline 18 & Tin & $\begin{array}{l}\text { Bearing metal and thrust metal bushes, wrist and piston pins, pistons, rings, oil } \\
\text { seals, solder. }\end{array}$ \\
\hline 19 & Titanium & Bearing hub wear, compressor blades and discs especially in aero engines. \\
\hline 20 & Zinc & Brass components, neoprene seals, grease, coolant leaks, oil additives \\
\hline
\end{tabular}




\section{Table-5:}

\begin{tabular}{|c|c|c|}
\hline $\begin{array}{l}\text { Basic wear debris } \\
\text { feature }\end{array}$ & $\begin{array}{l}\text { Measurement descriptor and } \\
\text { possible working definition }\end{array}$ & Reason for selection \\
\hline Size & $\begin{array}{l}\text { Largest calculated diameter } \\
\text { (LCD) } \\
\text { The LCD descriptor is proposed, } \\
\text { based on a smart algorithm } \\
\text { incorporating all the possible } \\
\text { OSM size measurement } \\
\text { descriptors. The algorithm will } \\
\text { return the largest calculated } \\
\text { diameter. }\end{array}$ & $\begin{array}{l}\text { From the discussion } 3.1 \text {, all the OSM parameters use } \\
\text { visual dimensional analysis. This measures a dimension } \\
\text { of wear debris bodily appearance, representing surface } \\
\text { degradation of the component. So by using LCD as a size } \\
\text { measurement descriptor, the possible largest surface } \\
\text { degradation on the machine component may be } \\
\text { determined. This degradation may also provide a good } \\
\text { diagnosis of wear severity. Wear severity is a critical } \\
\text { diagnosis of health, as indicated by the size of wear } \\
\text { debris. }\end{array}$ \\
\hline Quantity & $\begin{array}{l}\text { Number and Density determiner } \\
\text { (NDD) } \\
\text { NDD is proposed as to be a } \\
\text { combination of number and } \\
\text { derived density descriptors of } \\
\text { quantity feature, derived from } \\
\text { mass and volume descriptors. }\end{array}$ & $\begin{array}{l}\text { By proposing a combination of number and density, the } \\
\text { main aim is to determine the wear rate of machine } \\
\text { component in terms of number (counts of debris) as well } \\
\text { as in terms of physical level. Through combination of } \\
\text { these two a diagnosis of health and wear rate will be } \\
\text { achieved. }\end{array}$ \\
\hline Size distribution & $\begin{array}{l}\text { Statistical probability distributor } \\
\text { (SPD) } \\
\text { SPD is proposed as an algorithm } \\
\text { combining four statistical } \\
\text { descriptors (mean, standard } \\
\text { deviation, skewness and } \\
\text { kurtosis) with probability based } \\
\text { descriptors. It will initially } \\
\text { determine the values of the } \\
\text { descriptors and determine the } \\
\text { trend for the observed wear } \\
\text { debris sample. The trend will be } \\
\text { guided for predictive curve } \\
\text { fitting from probability based } \\
\text { descriptors. }\end{array}$ & $\begin{array}{l}\text { By utilizing the SPD descriptor, trends of the size } \\
\text { distribution in wear debris samples can be handled. }\end{array}$ \\
\hline Shape & $\begin{array}{l}\text { Shape factor (SF) } \\
\text { SF is proposed as a combination } \\
\text { of aspect ratio, fractal dimension } \\
\text { and curvature determiner } \\
\text { descriptors of the shape features } \\
\text { of wear debris. Aspect ratio is } \\
\text { proposed for determination of } \\
\text { physical form, fractal dimension } \\
\text { is proposed for surface texture } \\
\text { and a curvature determiner is } \\
\text { proposed for analyzing edge } \\
\text { details of wear debris. }\end{array}$ & $\begin{array}{l}\text { By using the SF, all three shape feature basics (physical } \\
\text { form, surface texture and edge detail) are } \\
\text { comprehensively described and measured. }\end{array}$ \\
\hline Composition & $\begin{array}{l}\text { Derived macro property factor } \\
\text { (DMPF) } \\
\text { DMPF is proposed to be as a } \\
\text { combination of macro property } \\
\text { descriptors like colour, specific } \\
\text { heat capacity, conductivity etc. }\end{array}$ & $\begin{array}{l}\text { The determination of novel research directions is the } \\
\text { main aim of the DMPF descriptor, because no mature } \\
\text { research is available for determining such a descriptor } \\
\text { that can utilize the physical properties of wear debris for } \\
\text { the determination of its composition. }\end{array}$ \\
\hline
\end{tabular}


Figure 1:

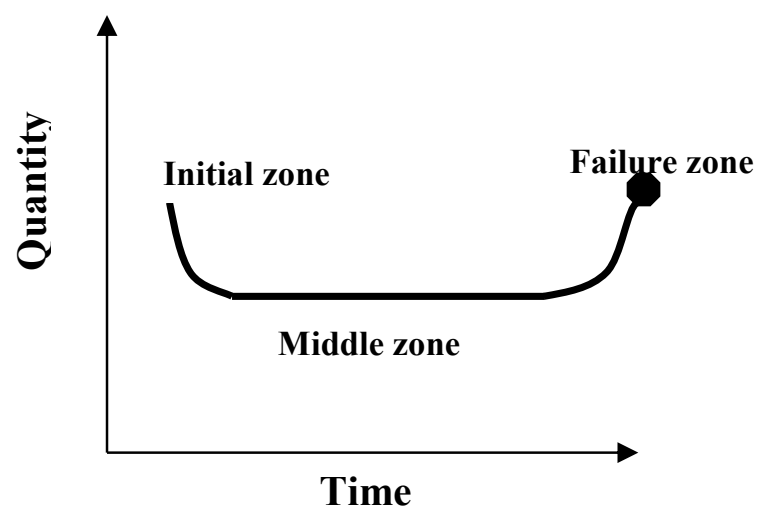

Figure 2:

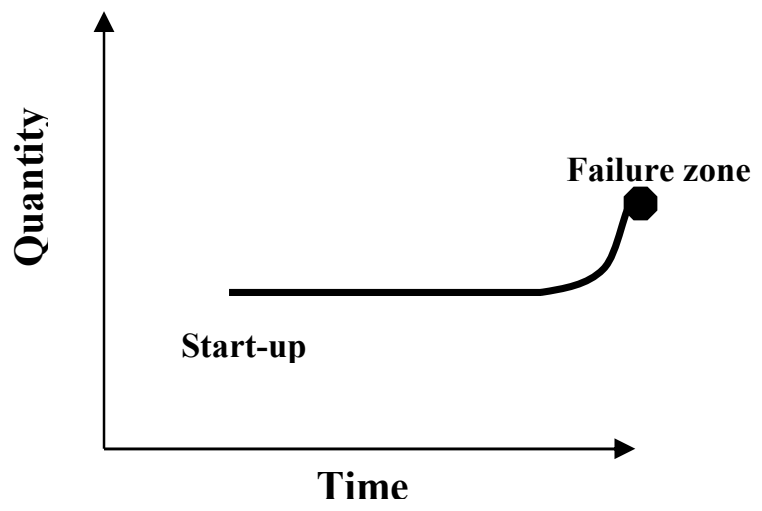

Figure 3:

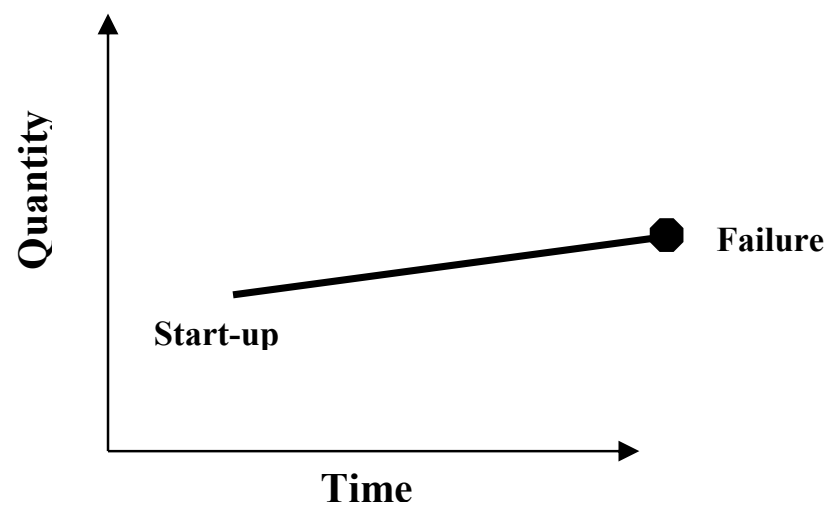


Figure 4:

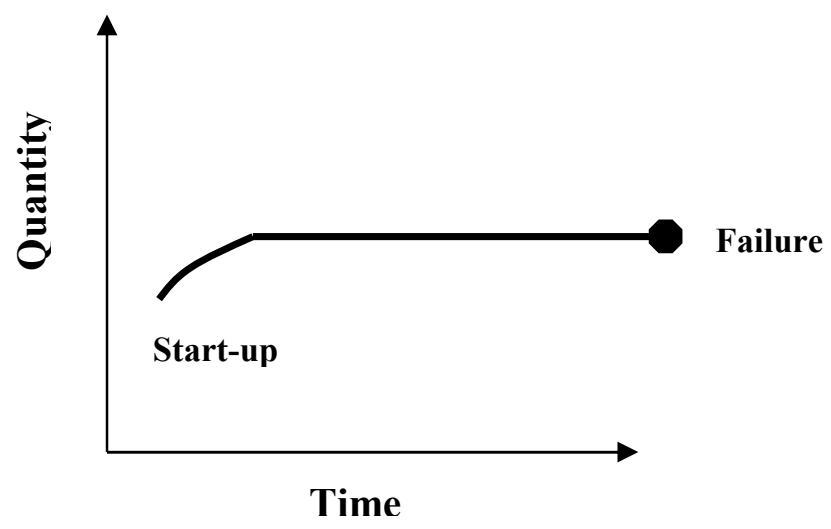

Figure 5:

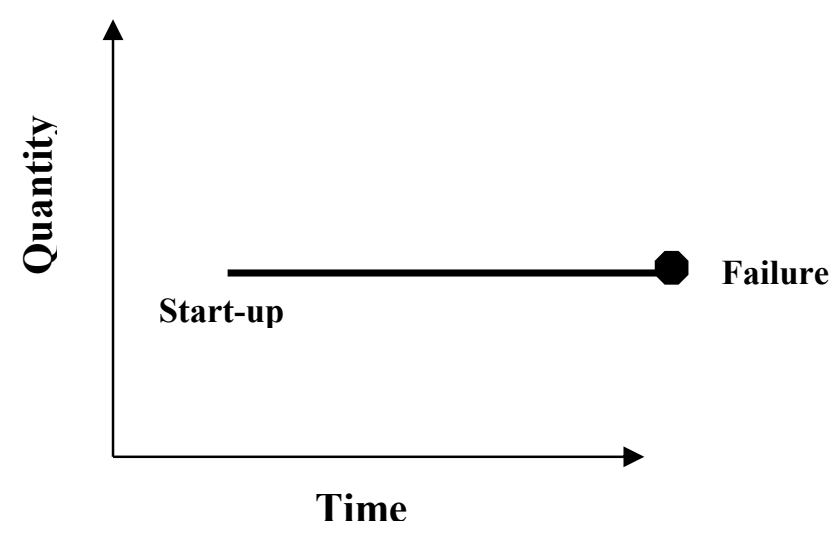

Figure 6:

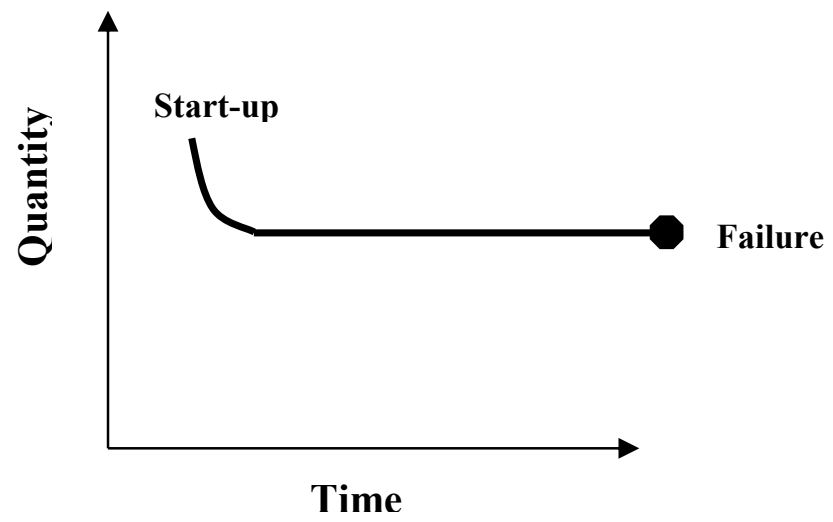


Figure 7:

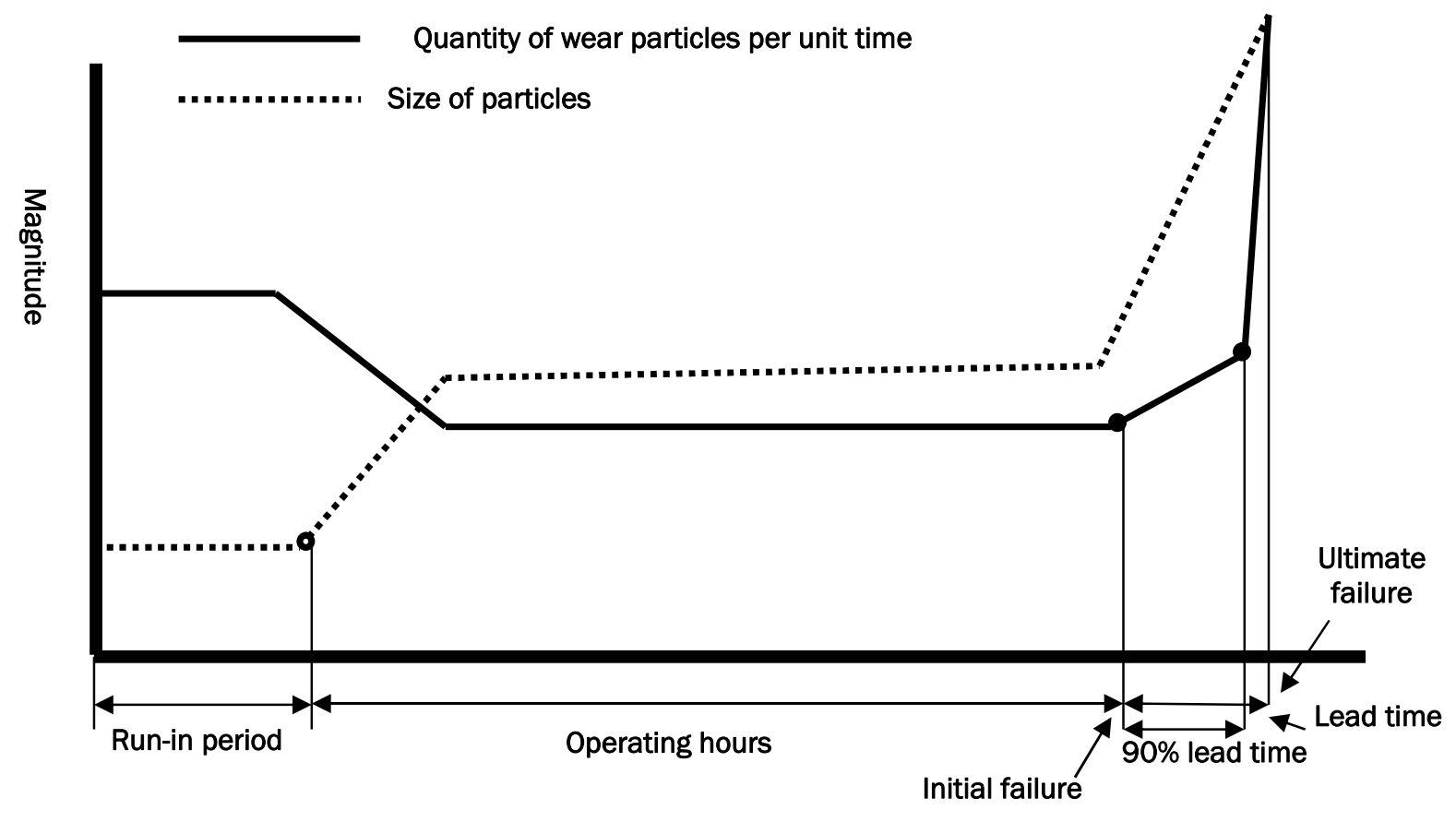


Figure 8:
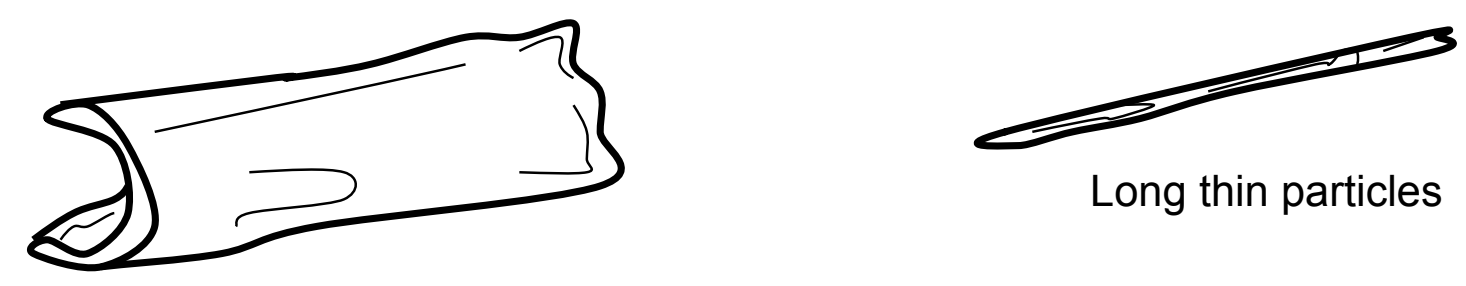

Rolls

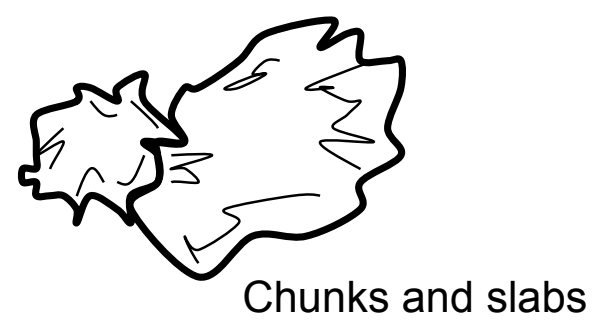

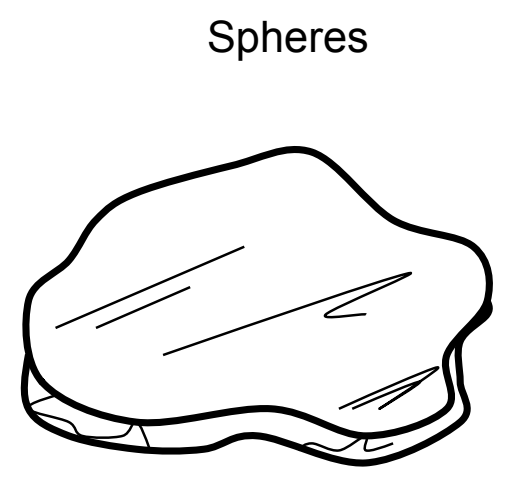

Platelet and flakes

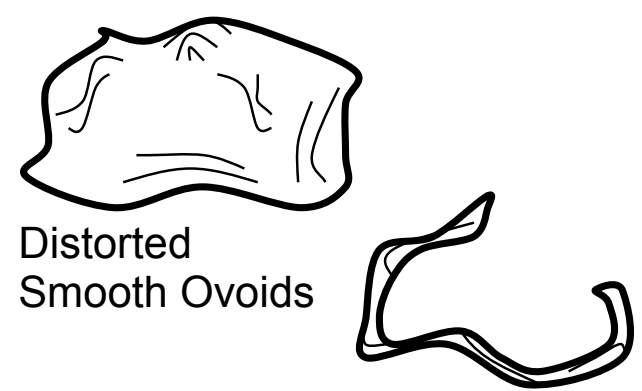

Curls, Spirals and Slivers 
Figure 9:

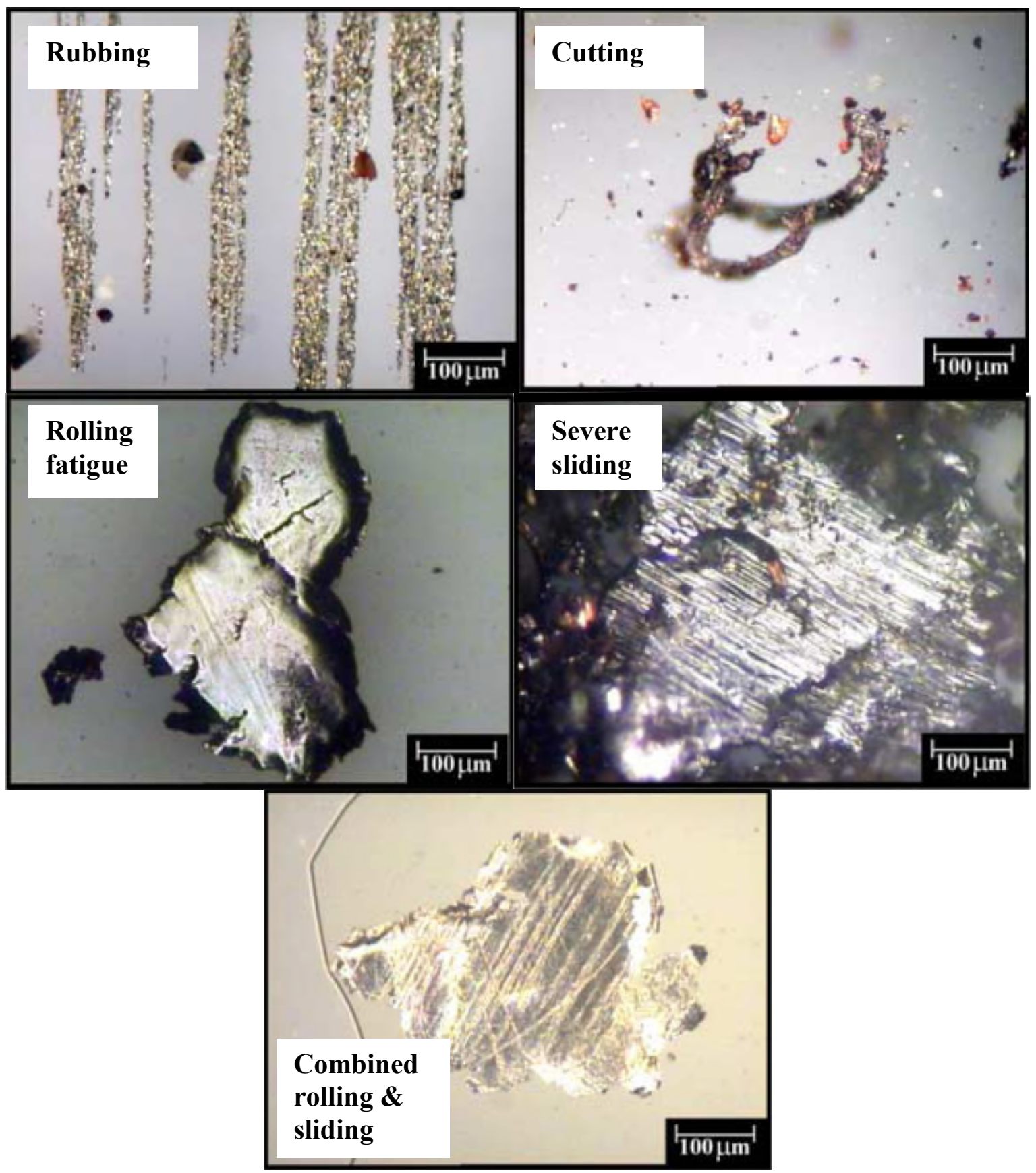


Figure 10:

\begin{tabular}{|c|l|l|}
\hline Wear Mode & Wear Type \\
\hline Abrasion & Rubbing \\
\hline Adhesion & \begin{tabular}{l} 
Cutting \\
\hline Rolling \\
fatigue
\end{tabular} \\
\hline Fatigue & $\begin{array}{l}\text { Rolling and } \\
\text { sliding }\end{array}$ \\
\hline $\begin{array}{l}\text { Severe } \\
\text { sliding }\end{array}$ \\
\hline
\end{tabular}


$\underline{\text { Figure 11: }}$

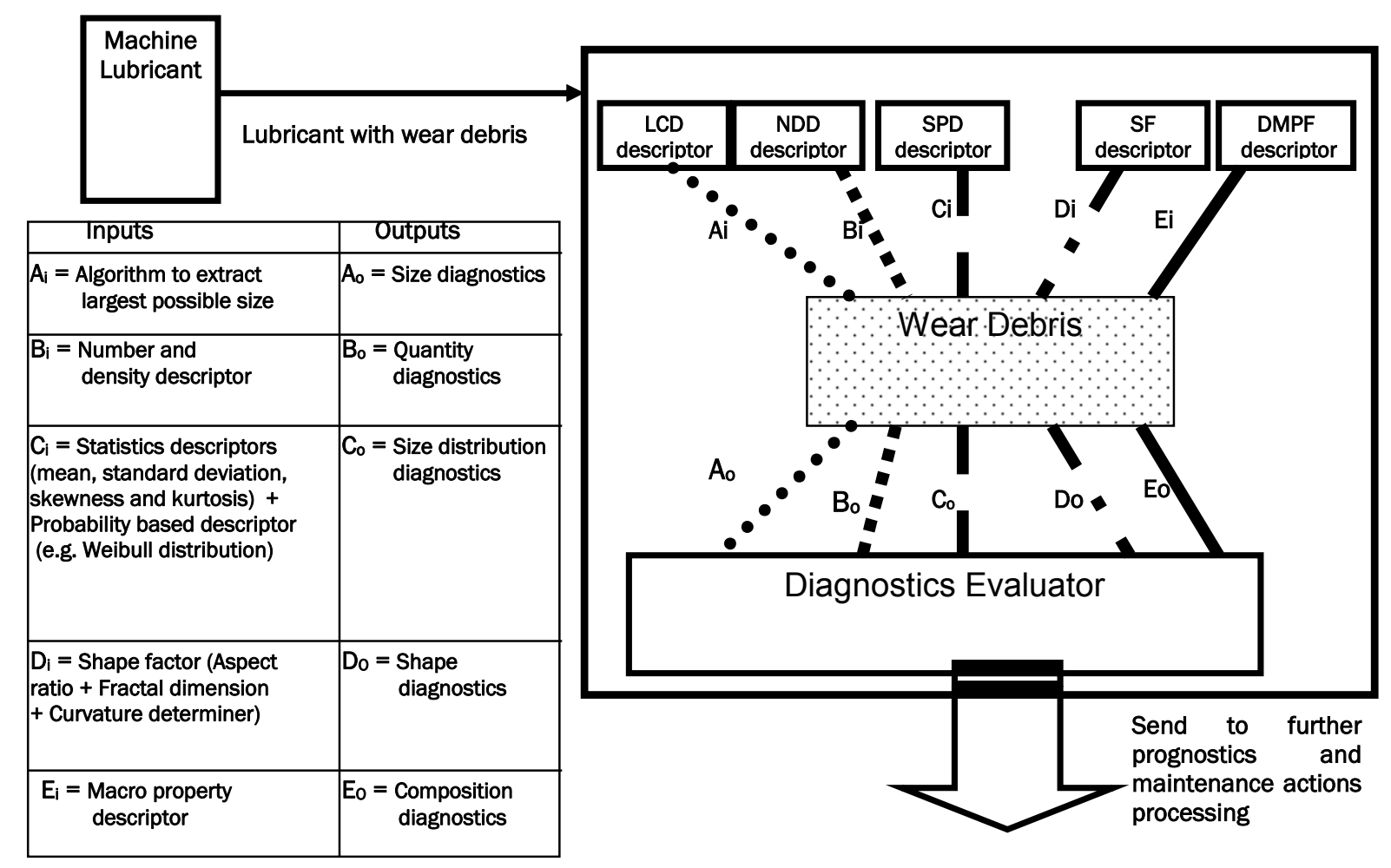


Figure 12:

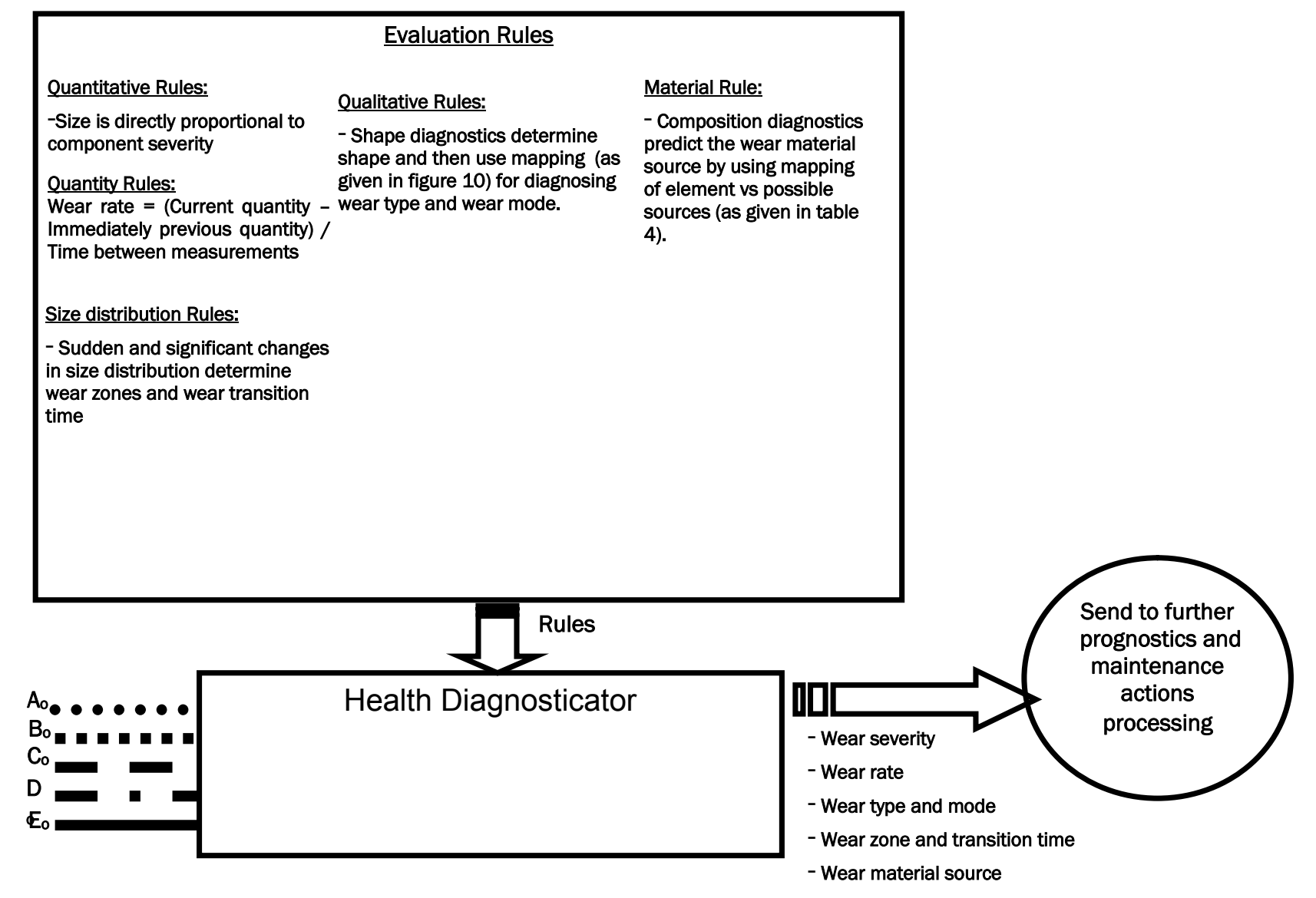




\section{REFERENCES}

1. B. J. Roylance and T. Hunt, 'Wear debris analysis', First edition, Coxmoor Publishing, 1999.

2. N. Myshkin, L. Markova and A. Grigoriev, 'Condition Monitoring and Predictive Analysis of Tribosystems by Wear Debris', Practising Oil Analysis Magazine, March 2005.

3. K. Xu, A.R. Luxmoore and F. Deravi, 'Comparison of shape features for the classification of wear particles', Engineering Applications of Artificial Intelligence, Vol 10, No 5, pp 485 - 493, 1997.

4. T. Hunt, 'Wear debris analysis and particle detection in liquids', Elsevier Applied Science, 1993.

5. A. Davis, 'Handbook of condition monitoring techniques and methodology', First edition (edited), Chapman and Hall, 1998.

6. M. Flanagan, J. R. Jordan and H. W. Whittington, 'Wear debris detection and analysis techniques for lubricant based condition monitoring', Journal of Physics, Vol 21, No 11, pp 1011-1016, 1988.

7. B. J. Roylance, J. A. Williams and R. Dwyer Joyce, 'Wear debris and associated wear phenomena fundamental research and practice', Proceedings of Institution of Mechanical Engineers, Vol 214, Part J, pp 79 - 105, February 2000.

8. T. P. Sperring and T. J. Nowell, 'Syclops - A qualitative debris classification system developed for RAF early failure detection centers', Tribology International, Vol 38, No 10, pp 898- 903, June 2005.

9. \#\#V.F.Leavers, 'Classifying wear debris particles with automatic image analysis', Article in Practicing Oil Analysis Magazine, November 2005.

10. B. J. Roylance and S. Raadnui, 'The morphological attributes of wear particles - their role in identifying wear mechanisms', Wear, Vol 175, No 1, pp 115 -124, 1994.

11. L. Hentschel and N. W. Page, 'Selection of descriptors for particle shape characterization', Journal of Particle and Particle System characterization, Vol 20, No 1, pp 25 -38, February 2003.

12. W. Huysman, 'Utilizing analytical Ferrography for root cause analysis and failure prevention', http://www.reliabilityweb.com/art05/analytical_ferrography.htm. [Last accessed: May 2006]

13. S. Raadnui and B. J. Roylance, 'Classification of wear particle shape', Lubrication Engineering, Vol 51, No 5, pp 432 437, 1995.

14. G. W. Stachowiak, 'Wear Materials, Mechanisms and Practice', Edited, John Wiley and Sons, 2005.

15. J. Fitch, 'A much closer look at particle contamination', Practising Oil Analysis Magazine, September 2005.

16. T. Allen, 'Particle size measurement', Fifth edition, Vol 1, Chapman and Hall, 1997.

17. D. P. Anderson, 'Wear particle atlas', Report NAEC-92-163, Naval Air Engineering Centre, 1982.

18. R. Bowen et al, 'Ferrography', Tribology international, Vol 9, pp 109-115, 1976.

19. K. Leschonski, 'Representation and Evaluation of Particle Size Analysis Data', Journal of Particle and Particle System Characterization, Vol 1, No 3, pp 89 - 95, 1984.

20. J. Moubray, 'Reliability-centred maintenance', Second edition, Butterworth Heinemann, 1997.

21. M. Neale and associates, 'Guide to the condition monitoring of machinery', HMSO, 1979.

22. G. Pocock, 'Particle size analysis for machinery health monitoring', Nature, Vol 270, pp 414 - 415, 1977.

23. N. R. J. Fieller et al, 'Statistics of particle size data', Applied statistics, Vol 41, No 1, pp 127- 146, 1992.

24. B. J. Roylance and G. Pocock, 'Wear studies through particle size distribution-I', Wear, Vol 90, No 1, pp 113 -136, 1983.

25. Heywood, 'Symposium on particle size analysis', Institution of Chemical Engineering Supplement 25, 14, 55, 1947.

26. A. Starr, 2005, Merging Condition Monitoring Data and Knowledge, I Mech E Seminar 1116: The use of on-line sensor technology in condition monitoring to improve maintenance, Farnborough UK

27. Y. Jin and C. Wang, 'Spherical particles generated during the running-in period of a diesel engine', Wear, Vol 131, No 2, pp $315-328,1989$.

28. S. Raadnui, 'Wear particle analysis - utilization of quantitative computer image analysis: a review', Tribology International, Vol 38, No 10, pp 871 -878, October 2005.

29. J. Fitch, 'Maximizing fault detection in rotating equipment using wear debris analysis', Practising Oil Analysis Magazine, March 1999. 
2006-08-01

\section{Wear debris: basic features and machine health diagnostics}

Khan, M. A.

British Institute of Non-destructive Testing

M.A. Khan and Andrew G. Starr. Wear debris: basic features and machine health diagnostics.

Insight - Non-Destructive Testing \& Condition Monitoring, Volume 48, Number 8, 1 August 2006, pp470-476

http://dx.doi.org/10.1784/insi.2006.48.8.470

Downloaded from Cranfield Library Services E-Repository 